\title{
Un diálogo entre José Hernández y el Romanticismo (Don Juan Tenorio (2000) en la Compañía Nacional de Teatro Clásico)
}

\author{
Olivia Nieto Yusta ${ }^{1}$ \\ A dialogue between José Hernández and Romanticism \\ (Don Juan Tenorio (2000) in the National Classical \\ Theatre Company).
}

\begin{abstract}
RESUMEN
El Romanticismo constituye la principal fuente de inspiración del pintor, grabador, ilustrador y escenógrafo José Hernández. Motivos como la ruina, el paso del tiempo, la muerte, la melancolía, la noche o la angustia existencial conforman su imaginario artístico. Con motivo del estreno de Don Juan Tenorio en el año 2000, dirigido por Eduardo Vasco para la

Compañía Nacional de Teatro Clásico, José Hernández diseñó una escenografía que traslada el lenguaje de su pintura al teatro, en la puesta en escena del que se considera el drama romántico español por excelencia. Siguiendo la metodología de la semiótica teatral, que concibe el teatro como la unión de texto y espectáculo, las siguientes páginas hacen un recorrido por los telones pintados empleados en cada

uno de los actos del drama, un recurso que se ha convertido en una constante en su obra escenográfica y que plasma a la perfección la unión de escenografía y

texto dramático.
\end{abstract}

ABSTRACT

Romanticism is the principal inspiration of the painter, engraver, illustrator and scenographer José Hernández. Elements as ruins, passage of time, death, melancholy, the night or existential anguish compose his artist imaginary. Because of the première of Don Juan Tenorio in the 2000, directed by Eduardo Vasco for the National Classical Theatre Company, José Hernández designed a scenography which translates the language of his paintings to the theater, in the staging of which is considered the quintessential spanish romantic drama. Following the methodology of the theater semiotics, which defines 'theater' as the union of text and spectacle, the following pages revise the painted curtains used in the different parts of the drama, a resource that has become a constant in his stage designs and a perfect reflection of the union of scenography and dramatic text.

\footnotetext{
${ }^{1}$ Grupo de Investigación del SELITEN@T (UNED). Departamento de Literatura Española y Teoría de la Literatura de la Facultad de Filología de la Universidad Nacional de Educación a Distancia. Paseo Senda del Rey nº 7, 28040 Madrid. Correo electrónico: olivianieto.nieto@gmail.com.
} 
PALABRAS CLAVE

José Hernández, Romanticismo, Don Juan Tenorio, escenografía, Compañía

Nacional de Teatro Clásico, Eduardo Vasco, telón pintado, sublime.
KEY WORDS:

José Hernández, Romanticism, Don Juan Tenorio, scenography, National Classical Theatre Company, Eduardo Vasco, painted curtains, sublime.

A partir de la exposición José Hernández y el teatro. 1973-20072 (Nieva, 2008) que se celebró en la Capilla del Oidor de Alcalá de Henares, entre el 6 de junio y el 31 de agosto de 2008, se ha puesto de relieve una de las facetas artísticas menos conocidas de José Hernández: la teatral. Sus grabados, pinturas e ilustraciones le han proporcionado reconocimiento mundial, eclipsando el valor de su aportación plástica a las artes escénicas, cuyo inicio se remonta a 1974 con Danzón de exequias de Michel de Ghelderode, representada en Ditirambo Teatro Estudio de Madrid $^{3}$.

La presencia de lo teatral en la obra de José Hernández ha sido constante a lo largo de toda su trayectoria, y no algo meramente exclusivo de la mencionada exposición del 2008. Desde que comenzara en la década de los setenta, ha diseñado escenografías, figurines, máscaras y carteles para teatro y ópera junto a dramaturgos como Francisco Nieva, Miguel Narros, Eduardo Vasco, Juan Carlos Pérez de la Fuente, Juan Antonio Quintana, Joaquín Vida o José Luis Gómez.

No sólo con motivo de abordar su colaboración en la Compañía Nacional de Teatro Clásico a raíz del montaje Don Juan Tenorio (2000), dirigido por Eduardo Vasco, ofrecemos el estudio de sus composiciones escenográficas. Es necesario aplicar una lectura estrictamente teatral a su obra artística por varios motivos. Por un lado, todas sus composiciones, tanto en grabado como en pintura y escenografía, están concebidas conceptualmente a partir de la imagen de lo efímero, la descomposición, el paso del tiempo y la muerte; una idea que, de alguna manera, viene a ser la esencia del teatro en su puesta en escena: un acto único e irrepetible. La palpable influencia de Juan de Valdés Leal, pintor español del siglo XVII, y

\footnotetext{
${ }^{2}$ Francisco Nieva acompaña este catálogo con un texto en el que hace un breve recorrido por los recursos escenográficos que han conocido las sucesivas civilizaciones occidentales (Antigüedad Clásica, Edad Media, Renacimiento, Barroco, etc.), para a continuación desvelar las fuentes de José Hernández y su admirable capacidad para fusionar dos tendencias estéticas: el clasicismo vernáculo grecolatino y la dinámica medievalista.

${ }^{3}$ Este reconocimiento como pintor, grabador e ilustrador explica la escasa atención que José Hernández presta a sus diseños escénicos en su página web (http://www.jose-hernandez.com), a diferencia de su obra plástica. En ella, apenas se ofrece documentación gráfica, y la documentación bibliográfica referente a su producción teatral es prácticamente inexistente. Esto es tan sólo un reflejo de la laguna teórica en la que está inmersa la producción teatral de nuestro autor. En este sentido, he abordado Los montajes de José Hernández en la Compañía Nacional de Teatro Clásico, en el Trabajo de Fin de Máster del máster universitario en «Formación e Investigación Literaria y Teatral en el Contexto Europeo», de la UNED (defendido en marzo de 2012), bajo la dirección del profesor José Romera Castillo.
} 
sus vanitas, refleja el constante interés de José Hernández por la degradación de todos los componentes de sus obras, como restos de construcciones ofrecidas bajo la visión romántica de la ruina, u hombres cuya carne descompuesta deja entrever su estructura ósea. A ello se suma el efecto producido por la presencia de ricos materiales en suelos, telas y construcciones que, bajo los efectos del paso del tiempo, obtienen una dimensión teatral, distante de un espacio concreto y reconocible. Se trata de ofrecer un espacio ficticio, una arquitectura pictórica que evoca las visiones de la pintura simbolista del siglo XIX. Muchos de estos conceptos encuentran cierto paralelismo con algunas obras dramáticas del Siglo de Oro en las que ha trabajado, sin desdeñar la presencia de una atmósfera propia del imaginario surrealista. Por otro lado, su formación como delineante y su actividad de grabador explica el riguroso tratamiento técnico del dibujo al que son sometidas sus pinturas, grabados y escenografías, en las que la perspectiva se impone con precisión, proporcionando a sus composiciones, tanto pictóricas como escenográficas, las dimensiones y exigencias de un escenario teatral ${ }^{4}$.

Por todo esto, puede afirmarse que José Hernández entabla un estrecho diálogo con el teatro y la puesta en escena en dos sentidos: uno, de carácter pictórico y estilístico, y otro de carácter técnico. A ello, cabe añadir que son dos las líneas que caracterizan su obra: la clásica y la romántica. La línea clásica ofrece un meticuloso tratamiento de la perspectiva científica junto a reminiscencias renacentistas, mientras que la línea romántica queda patente a través de la melancolía o terror que se desprende de sus composiciones, así como la dialéctica establecida entre las sensaciones de atracción (fuerte halo de misterio y enigma) y repulsión (por la descomposición de la materia).

En este trabajo, el análisis de la escenografía de José Hernández se inserta en el campo de la semiótica teatral, en el que no cabe la idea preconcebida (que hoy goza de relativa aceptación) de que el hecho teatral sólo puede ser texto o espectáculo. La escenografía de José Hernández es un claro ejemplo de la unión entre texto y puesta en escena. Su obra pictórica y grabada, tiene un acentuado carácter figurativo y teatral en la que el misterio, así como los espacios y situaciones inquietantes, juegan un marcado protagonismo; su obra, en este sentido, presenta un perfil narrativo y literario que consigue una cabal integración entre texto y representación, así como una original concepción del espacio escénico. Su esce-

\footnotetext{
${ }^{4}$ En 2005 ve la luz una monografía: José Hernández de Francisco Calvo Serraller. Su autor advierte algunos de los referentes del pintor como el realismo mágico de los sesenta, el surrealismo de Dalí y Ernst, la pintura metafísica de De Chirico (1888-1978), la tradición clásica, etc. Su formación como delineante se hace patente en un mundo de pesadillas en el que cabe lo monstruoso y lo fantástico. Calvo Serraller se detiene en sus creaciones teatrales en las que se repite la presencia de los recursos iconográficos vistos en sus grabados: las ruinas entran en diálogo con lo orgánico, se dota a la perspectiva de un carácter mítico, el espacio se convierte en una evocación de lo onírico, las arquitecturas clásicas, derruidas, están compuestas de mármoles, arcos de medio punto, columnas con capiteles, todo bajo la óptica de unos objetos alterados por el paso del tiempo. Con todo esto, concluye que estamos ante un teatro de sombras que encuentra el germen de Buontalenti y Giulio Parigi en su escenografía, y la huella de Altdorfer y Hercules Pietersz Seghers en el carácter misterioso que impregna toda su obra.
} 
nografía no es solamente una ambientación, sino la creación de unos espacios plásticos dotados de una intensa y original tensión que acentúa el valor y efecto dramático de la obra. El ejemplo más claro lo encontramos en este Don Juan Tenorio, donde las acotaciones de Zorrilla sirvieron a Hernández de inspiración, tanto en las escenografías empleadas en el montaje como en los bocetos finalmente desechados.

Pero antes de adentrarnos en el montaje teatral de esta obra, es necesario hacer constar la función que desempeña la escenografía, artística y temáticamente. La escenografía de un montaje teatral conoce una evolución que corre de forma paralela al texto dramático, adaptándose de una u otra forma a la ambientación, la temática, las pasiones de los personajes, la idea del director de escena, etc., manteniéndose la impronta artística del escenógrafo. Pero además de reforzar o complementar el texto dramático, debe concebirse como una creación artística en sí misma, un aspecto que cobra fuerza en el caso de José Hernández que, al igual que introduce arquitecturas teatrales en sus pinturas y grabados, trata sus escenografías como cuadros tridimensionales donde el carácter pictórico es el leitmotiv. Así pues, el teatro es un «todo» en el que conviven distintas disciplinas (interpretación, dirección, iluminación, vestuario, música, escenografía...), pero todas ellas se alzan como expresiones artísticas únicas.

A partir de la colaboración de José Hernández en Don Juan Tenorio, un espectáculo dirigido por Eduardo Vasco, se pretende abordar la presencia de lo teatral en su obra pictórica y gráfica, aplicando a su vez una mirada inversa con la que valorar la presencia de lo siniestro y lo romántico como fundamento de sus escenografías.

\section{LA IMAGEN ROMÁNTICA COMO COMÚN DENOMINADOR A DON JUAN TENORIO Y JOSÉ HERNÁNDEZ.}

No es éste el lugar en el que hacer un estudio del Romanticismo, pero sí en el que atender a la conexión existente entre la obra gráfica, pictórica y escenográfica de José Hernández.

A pesar del tiempo que separa a José Zorrilla de José Hernández, existe en ambos artistas un nexo común: una actitud ante la vida derivada del Romanticismo. En el caso del dramaturgo, como contexto histórico y espíritu de su tiempo, y en el del escenógrafo como actitud interior y fuente de inspiración temática y estética. José Zorrilla se vio inmerso en una época en la que determinados valores estaban aflorando por las circunstancias políticas del momento, como era un sentimiento de libertad nacional y política que afectó a todos los ámbitos de la vida española, y que poco a poco fue calando en nuestros intelectuales románticos, definiéndose la esencia estética de esta corriente. Pero hay tener en cuenta que la imagen romántica de España fue creada fundamentalmente por escritores, artistas y viajeros ex- 
tranjeros que a lo largo del siglo XIX visitaron nuestro país por diversas circunstancias. Las campañas napoleónicas pusieron en contacto a España y Europa dando a conocer a nuestros mejores pintores (Goya, Zurbarán o Murillo ${ }^{5}$ ) y consolidándose así la pintura clásica española 6 . Algunas figuras como Richard Ford, Lenbach, Mérimée o Delacroix contribuyeron a tal labor, aunque los mayores difusores fueron el Baron Taylor y T. Gautier. Francisco Calvo Serraller (VV.AA., 1981: 19-28) señala cómo los viajeros se sentían atraídos por el folklore, la pintura clásica, lo pintoresco de nuestros paisajes, gentes y costumbres, y que España representaba la puerta a Oriente y a las culturas árabe y africana. Curiosamente en el momento de mayor decadencia política, bajo el reinado de Fernando VII, es cuando España se convierte en referente europeo, alcanzando su punto culminante entre 1830 y 1850, momento en que el Romanticismo se instala oficialmente en toda Europa.

Aunque podemos aproximarnos al Romanticismo desde el punto de vista histórico, hay lecturas distintas como la de Francisco Nieva que sitúa el origen del Romanticismo español en nuestro teatro del Siglo de Oro:

Es difícil para los españoles definir el Romanticismo porque nosotros tenemos un prerromanticismo que es nuestro verdadero Romanticismo. Es el Romanticismo de nuestro teatro clásico. Nuestro teatro barroco, que ha parecido tan disparatado a los franceses en el siglo XIX, era un teatro romántico; es decir, les pareció excesivo a finales del siglo XVIII, y realmente era un teatro romántico. Nosotros como pueblo pobre, humillado, sobre todo en aquella época, hemos aceptado el veredicto francés sobre nuestro teatro clásico. Lo aceptamos en el siglo XVIII y Moratín lo siguió a raja tabla, aún con ciertas reservas; y naturalmente no pudimos imponer la idea de que el verdadero Romanticismo español está ya en Lope de Vega $^{7}$.

Isaiah Berlin (2000) ahonda en el origen del Romanticismo y para ello se remonta a Friedrich von Schlegel (1772-1829) que advierte como verdaderos estimulantes morales, políticos y estéticos la aparición de la Teoría del conocimiento de Johann Gottlieb Fichte (1762-1814), la Revolución Francesa (1789) y la publicación de la novela Wilhelm Meister (1796) de Goethe. La Teoría del conocimiento de Fichte indagó sobre el 'yo' a sabiendas de los obstáculos que habían percibido los empiristas del siglo XVIII, y estableció la imagen estereotipada del 'yo' romántico que ha llegado hasta nuestros días. En sus postulados expone cómo el individuo, cuando algo le conmueve, está ante lo que Fichte ha venido a llamar

\footnotetext{
${ }^{5}$ Véase el estudio de Ilse Hempel Lipschutz, Spanish Painting and the French Romantics. Cambridge, Harvard University Press, 1972. Hay traducción castellana, La pintura española y los Románticos Franceses, Madrid, Taurus, 1988.

${ }^{6}$ El teatro en el Madrid de la ocupación francesa es estudiado por Ana María Freire López en El teatro español entre la Ilustración y el Romanticismo. Madrid durante la Guerra de la Independencia, Madrid, Iberoamericana, 2009.

7 Transcripción de un fragmento de la conferencia El drama romántico, pronunciada por Francisco Nieva el 20/05/1982, dentro del ciclo Romanticismo literario español (1830-1850), disponible en http://www.march.es/conferencias/anteriores/voz.aspx?id=1393.
} 
anstoss («el impacto»), un tipo de perturbación o agitación anímico-emocional que le hace ser consciente de su 'yo', y que sería la prueba de que el mundo es real y que no está ante algo imaginario. Los postulados de Fichte fueron adoptados por los románticos, iniciando la tarea de atender a su 'yo' en toda manifestación de creatividad. En este sentido, F. W. von Schelling (1775-1854) encuentra una especial conexión entre arte y hombre: la obra de arte recogería los impulsos vitales del hombre, inconscientes en el artista, que son un mero reflejo de las pulsaciones de la naturaleza. Así, según Schelling, la obra de arte ejercería un efecto vital sobre el hombre que la observa. En la misma línea se encuentran las aportaciones de Edmund Burke recogidas en su tratado Indagación filosófica sobre el origen de nuestras ideas acerca de lo sublime y de lo bello (1757), organizado en capítulos que indagan en categorías estéticas como el gusto, la belleza, el temor, la alegría y el pesar, la infinidad o lo sublime, entre otras; al hablar De lo sublime Burke viene a corroborar los postulados de Fichte y Schelling:

Todo lo que resulta adecuado para excitar las ideas de dolor y peligro, es decir, todo lo que es de algún modo terrible, o se relaciona con objetos terribles, o actúa de manera análoga al terror, es una fuente de lo sublime; esto es, produce la emoción más fuerte que la mente es capaz de sentir. Digo la emoción más fuerte, porque estoy convencido de que las ideas de dolor son mucho más poderosas que aquéllas que proceden del placer. Sin duda alguna, los tormentos que tal vez nos veamos obligados a sufrir son mucho mayores por cuanto a su efecto en el cuerpo y en la mente, que cualquier placer sugerido por el voluptuoso más experto, o que pueda disfrutar la imaginación más viva y el cuerpo más sano y de sensibilidad más exquisita (Burke, 2001: 29).

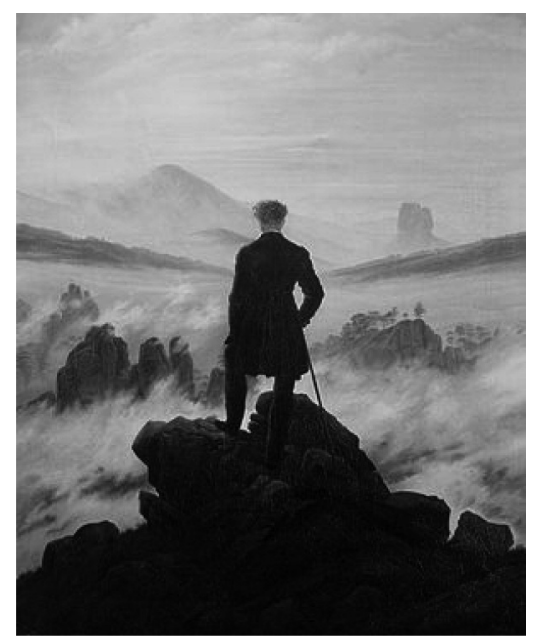

Fig. 1. Viajero frente a un mar de niebla (1817-1818), C. D. Friedrich. Kunsthalle de Hamburgo, Alemania.

\footnotetext{
8 Todas las imágenes de la obra artística de José Hernández, contenidas en este trabajo, pertenecen al archivo del artista.
} 


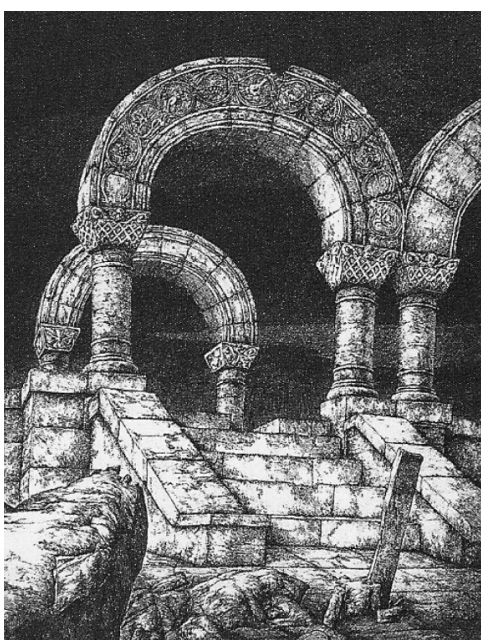

Fig. 2. Miserere III (1984). Aguafuerte. J. Hernández8

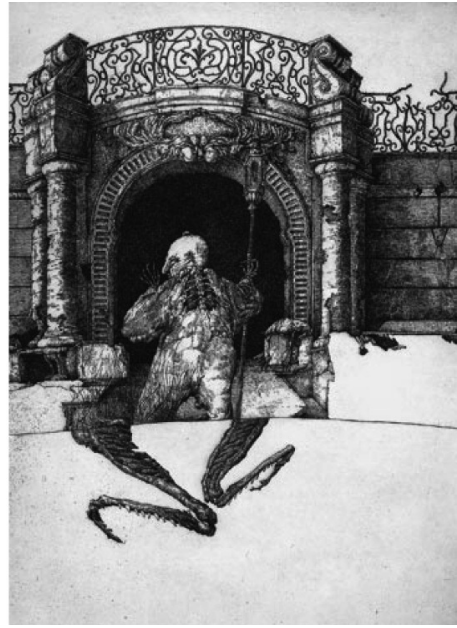

Fig. 3. Bacanal IV (1975). Grabado para la edición de Bacanal de Luis Buñuel. J. Hernández.

Además de hablar expresamente de lo sublime, en otros capítulos Burke reflexiona sobre algunas categorías que están estrechamente ligadas a este principio estético, como es el terror, principio dominante de lo sublime, la vastedad o la infinidad; incluso el color es portador de la sublimidad en cierta medida. En este sentido, el pintor Caspar David Friedrich (1774-1840), sin duda, supo trasladar a su pintura este poderoso sentimiento (lo sublime) que define por antonomasia las inquietudes existenciales del hombre romántico (Fig. 1).

Todas estas cuestiones que ahondan en el 'yo', y que ayudan a codificar la manera que el romántico tiene de enfrentarse al cosmos y la naturaleza, aparecen en la honda carga de subjetividad con que José Hernández dota a su pintura. La idea de lo sublime expuesta por Burke no hace sino definir la naturaleza de sus composiciones y el efecto que éstas provocan en el espectador. Por un lado, hallamos la idea de infinito en los seres y arquitecturas que protagonizan sus grabados, pinturas y escenografías, condenados a la eternidad al transmitir la quietud de una ruina que, a pesar de verse afectada por el paso del tiempo, permanece impasible a lo largo de los siglos. A su vez, la referencia al terror es también un elemento identificador de su obra, lograda a través de la presencia de seres deformes que ocupan espacios siniestros que constantemente evocan la muerte con sus carnes putrefactas, todo ello envuelto en un halo de misterio y oscuridad, otra cualidad que Burke considera indispensable para que una cosa sea terrible y provoque todo tipo de miedos e inseguridades en el receptor de tales imágenes.

En relación con esto, no deben olvidarse las características de la paleta de José Hernández, formada por una gama apagada de ocres, marrones, grises, negros y sepias que acentúan los efectos de terror, infinidad y oscuridad (Fig. 2, Fig. 3), en coincidencia con las orientaciones de Burke: 
Los colores vivos o alegres (salvo tal vez un rojo fuerte que es alegre) no son indicados para producir grandes imágenes. Una montaña inmensa cubierta con un césped verde resplandeciente no se puede comparar en este aspecto con una oscura y lóbrega; un cielo nublado es más grandioso que uno azul; y la noche es más sublime y solemne que el día. Por consiguiente, en la pintura histórica los colores alegres y chillones nunca pueden surtir un efecto feliz: y en los edificios, cuando se pretende alcanzar el mayor grado de lo sublime, los materiales no deben ser blancos, ni verdes, ni amarillos, ni azules, ni de un rojo pálido, ni violeta, ni manchados, sino de colores tristes y oscuros como negro y marrón, o muy morado y parecidos (Burke, 2001: 61).

Pero en el caso de José Hernández también se trata de una categoría que se ha supuesto como propia de la pintura española y, en concreto, de la imprenta goyesca que ha pervivido de forma especial en ella entre 1950 y 1980 (Nieto Alcaide, 1993: 20-29).

\section{LA ESCENOGRAFÍA DE JOSÉ HERNÁNDEZ EN DON JUAN TENORIO}

Este trabajo se centra exclusivamente en la escenografía diseñada por José Hernández para Don Juan Tenorio, a partir de la cual se pretenden esbozar las relaciones existentes entre su pintura y su teatro. Ello implica un estudio incompleto del montaje teatral, ya que la puesta en escena de una obra es un «todo», una unidad que no puede concebirse sin el vestuario, la iluminación, la música, la escenografía, la interpretación o el texto; cada uno de estos elementos goza de autonomía estética y discursiva, y requiere de un estudio pormenorizado que permita apreciar el espectáculo en su totalidad; pero por cuestión de espacio, resulta imposible llevarlo a cabo.

Don Juan Tenorio fue estrenada por la Compañía Nacional de Teatro Clásico el 1 de noviembre del 2000 en el Teatro Calderón de Valladolid y el 14 de noviembre del mismo año en el Teatro de la Comedia de Madrid $^{9}$, bajo la dirección de Eduardo Vasco ${ }^{10}$. No será la primera vez que José Hernández colabore con

\footnotetext{
${ }^{9}$ El análisis de la puesta en escena de Don Juan Tenorio por Eduardo Vasco se apoya, por un lado, en la grabación audiovisual realizada por el Centro de Documentación Teatral el 5/12/2000, y por otro, en la versión que hizo Yolanda Pallín para este montaje. En la correspondiente edición (Zorrilla, 2000) no aparece la numeración de los versos, por lo que se ofrecerá la referencia a la página o páginas correspondientes, cuando se considere necesario.

${ }^{10}$ He aquí la ficha técnica del espectáculo: versión: Yolanda Pallín; adaptación musical: Mariano Marín; figurines: Rosa García Andújar; iluminación: Miguel Ángel Camacho (A.A.I.); escenografía: José Hernández; dirección: Eduardo Vasco. Reparto por orden de intervención (según el estreno en el Teatro Calderón de Valladolid en noviembre de 2000): Don Juan Tenorio: Ginés García Millán; Doña Inés: Cristina Pons; Don Luis Mejía: José Tomé; Ciutti: Walter Vidarte; Brígida: Julia Trujillo; Don Gonzalo de Ulloa: Juan José Otegui; Doña Ana de Pantoja: Paca Lorite; Avellaneda: Jesús Fuente; Capitán Centella: Arturo Querejeta; Don Diego Tenorio: José Segura; Butarelli: José Luis Gago; Abadesa: Berta Labarga; Lucía: Eva Trancón; Escultor: Juan Antonio Quintana; Pascual: José Vicente Ramos; Tornera: Ana Lucía Billate; Alguacil I: Daniel Albaladejo; Alguacil II: Fernando Gil; Gastón: Gerardo Quintana; Miguel: Jorge Basanta. Espectáculo coproducido con el Centro Dramático Nacional, el Teatro Calderón de Valladolid, la Junta de Castilla-León y Caja Duero.
} 
Eduardo Vasco. Además de Don Juan Tenorio (2000) de José Zorrilla, han trabajado juntos en Amar después de la muerte (2005) de Calderón de la Barca, El castigo sin venganza (2005) de Lope de Vega (los tres montajes de la CNTC ${ }^{11}$ ), Los vivos y los muertos de Ignacio García May, una producción del Centro Dramático Nacional acogida en el Teatro Infanta Isabel de Madrid en 2000, y en la ópera El rey pastor de W. A. Mozart, con libreto de Pietro Metastasio y dirección musical de Jonathan Webb, que tuvo lugar en el Teatro Rosalía de Castro de A Coruña en 2007. El director conoce la obra gráfica y pictórica de Hernández y el pintor también sigue de cerca sus trabajos escénicos, lo que ha creado una buena comunicación entre ambos. Vasco siempre encuentra en él un mundo fantástico capaz de adaptarse a cualquier texto dramático y es por eso por lo que solicita su colaboración para este montaje.

Hay que tener en cuenta que siempre que se lleva a escena a uno de nuestros clásicos se abre un debate en torno a la manera que tiene cada director de enfrentarse a ellos, posicionándose necesariamente en una de las dos corrientes existentes: la de aquellos que optan por la postura más conservadora, y la de los que buscan aproximar al espectador del siglo XXI unos textos que tratan de verdades universales ${ }^{12}$. Eduardo Vasco, cuando recibió la propuesta de montar Don Juan Tenorio para la CNTC, supo que se enfrentaba a un auténtico desafío porque es un drama por todos conocido, que cuenta con las más variadas propuestas teatrales a sus espaldas ${ }^{13}$. El principal dilema era cómo ambientar la pieza teatral; o bien seguir la indicación de Zorrilla y ubicar el texto a mediados del siglo XVI, o apostar por una ambientación diferente. Finalmente optó por esta última y sumergir de lleno el drama de Zorrilla en el Romanticismo.

Así pues, a pesar de la acotación del autor que indica que estamos en 1545, los valores que se arrojan en este texto son plenamente románticos: la noche, el libertinaje, la muerte, el amor, la angustia existencial, la aparición de los muertos, la religión, el satanismo, la salvación por intervención divina, etc. Vasco se apoya también en el lenguaje empleado por Zorrilla en su drama, que es el de mediados del siglo XIX; es decir, todo contribuye a ambientar el montaje de Vasco

${ }^{11}$ Eduardo Vasco ocupa el cargo de director de la CNTC desde 2004 hasta 2011, por lo que el montaje de Don Juan Tenorio (2000) de José Zorrilla se limita a una colaboración externa del director con la compañía.

${ }^{12}$ El mismo debate gira en torno a la restauración de monumentos artísticos. Algunos restauradores optan por reconstruir las partes dañadas del edificio sin que se permita distinguir el original del añadido, una tendencia que instauró Eugène Viollet-le-Duc (1814-1879) a partir de sus escritos teóricos, y principalmente a través de sus restauraciones de monumentos medievales franceses que trataban de recuperar el edificio primitivo. La postura opuesta es consciente de que nuestro siglo, nuestra mirada, nuestros valores y nuestros criterios son muy distintos a los que llevaron a construir estos monumentos, por lo que es de obligación señalar las diferencias entre uno y otro u otros períodos para conocer así la genealogía de dicha construcción.

${ }^{13}$ Hasta el momento, la CNTC ha escenificado este mito en cinco ocasiones: en 1988 de la mano de Adolfo Marsillach, en 2000 bajo la dirección de Eduardo Vasco, un año más tarde (2001) lo sube a las tablas Jean-Pierre Miquel, en 2002 le toca el turno a Maurizio Scaparro, y finalmente Miguel Narros hace su particular puesta en escena en 2003. 
en la época romántica. Con todo ello, sólo quedaba diseñar un espacio escénico capaz de conseguir la unidad del conjunto. Es entonces cuando aparece José Hernández, cuya escenografía en opinión de Vasco es idónea para este montaje teatral. Rosa García Andújar, responsable de vestuario, contribuyó a este proyecto con diseños que persiguen la moda romántica, y la iluminación, a cargo de Miguel Ángel Camacho, se ha topado con la particularidad de que el drama sólo transcurre de noche, un dato que animó a Vasco a dotar a la escena de una luz esencialmente teatral.

José Hernández ha diseñado para Don Juan Tenorio un espacio escénico compuesto en su mayoría por varios telones pintados con los que ambientar las escenas que transcurren en exteriores e interiores, manteniendo un mismo discurso plástico que recoge el ideario de toda su trayectoria artística ${ }^{14}$. El hecho de que se haya decidido ambientar el drama de Zorrilla en el Romanticismo, una tendencia que sirve de inspiración temática y estética a José Hernández, dota a la puesta en escena de una acentuada armonía y homogeneidad. Hernández ha sabido integrar en su diseño los elementos propios del espíritu romántico: el tiempo, la soledad, las ruinas, la indagación en el «yo», la naturaleza, lo sublime y la nostalgia por los espacios medievales y exóticos. Su escenografía se adapta a las dos partes del drama; la primera es dinámica, vitalista, pasional y terrenal, con duelos y apuestas sobre actos delictivos condicionados por el tiempo y la noche; se suman el misterio, la muerte trágica de algunos personajes a manos del héroe, el secuestro de la dama, o la huida. La segunda parte se desarrolla bajo una atmósfera lúgubre y siniestra, un tanto sobrenatural, que remite al mundo de los muertos a través del panteón, los sepulcros, las estatuas funerarias y la noche. La escenografía de Hernández ha sabido reflejar las dos partes del drama, pero en toda la obra mantiene la misma esencia de misterio con el color sepia y gris de telones, módulos, muebles y vestuario: «La evolución era clara: de un mobiliario envejecido pero casi realista en el primer acto, pasábamos a un fantasmal mobiliario cubierto de sábanas en el acto segundo de la segunda parte, que formaba parte de ese mundo siniestro que sigue a Don Juan tras la muerte de Doña Inés» (Zubieta, 2004: 58).

${ }^{14}$ El telón pintado es una constante en las escenografías de José Hernández. Hoy en día responde a una tradición que está más que olvidada y que Francisco Nieva reivindica desde sus escritos teóricos. El uso del telón pintado, que desapareció en el momento en que el Naturalismo y el Realismo quisieron aplicar su rígido criterio de verosimilitud a las tablas, dotaba al escenario de una gran teatralidad, pero estas dos corrientes acabaron con esta característica esencial en el instante en que todo quería ser verdad, teniendo como resultado un efecto antiteatral. El teatro convencional muere con el Romanticismo, imponiéndose un sentido utilitario en el que no caben las telas pintadas. Habrá que esperar a Diaghilev y a García Lorca para volver a ver este tipo de telones, de riqueza estética, que resultan del todo «inútiles» desde el punto de vista teatral, tal y como reivindica Nieva. José Hernández es consciente del valor estético de los decorados y telones pintados en escena, hasta el punto de que éstos últimos se han convertido en una constante en su obra teatral. 


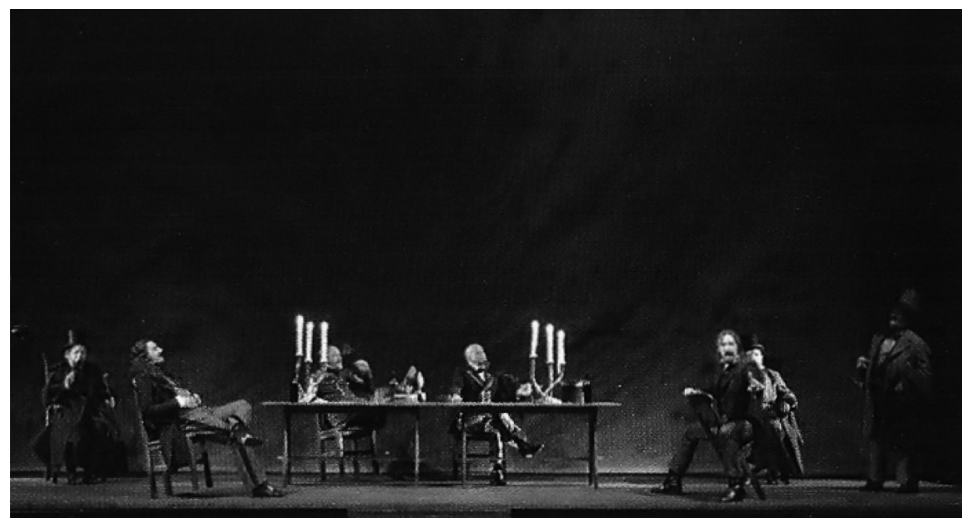

Fig. 4. Puesta en escena de Don Juan Tenorio. Hostería de Cristófano Buttarelli16.

Al comienzo del primer acto, el texto de José Zorrilla ofrece la siguiente acotación ${ }^{15}$ : «Hostería de Cristófano Buttarelli. Puerta en el fondo que da a la calle: mesas, jarros y demás utensilios propios de semejante lugar» (Zorrilla, 1993: 75). José Hernández decide abrir Don Juan Tenorio con un telón pintado, seguramente el recurso que mayor autonomía concede al escenógrafo en su faceta de pintor por ser prácticamente un lienzo de grandes dimensiones. El telón de la hostería es un torbellino de humo, un remolino que recuerda a las nubes de una tormenta o unas condiciones atmosféricas adversas donde no se pretende quitar protagonismo a los actores, sino tan sólo sugerir un fondo indeterminado (Fig.4).

La homogeneidad cromática se reduce al gris, ocre y sepia, unos colores idóneos para ambientar el primer acto en una hostería en la que se hace burla y fanfarronería sobre muertes, crímenes y conquistas amorosas a la luz de unos candelabros (recordemos que transcurre durante la noche). La recuperación temática y estética que José Hernández mantiene con principios y tópicos románticos, es palpable en esta escenografía, con más fuerza aún si cabe por tratarse del drama romántico español por excelencia.

La virulencia de la composición de este telón pintado (Fig. 5) presenta evidentes similitudes con uno de los pintores románticos ingleses más relevantes, WiIliam Turner (1775-1851), reconocido por la fuerza de unas pinturas que ya anunciaban el arte abstracto. Turner somete a todos los elementos a una constante transformación, donde imágenes e ideas se combinan en medio de un juego

${ }^{15}$ Puesto que José Hernández presenta una notable coherencia entre su escenografía y las acotaciones del texto original, este estudio se apoyará en ellas cuando convenga, para reflejar en qué grado las palabras del autor han podido inspirar al escenógrafo (y al director) de este montaje. Las ediciones de Don Juan Tenorio que se van a manejar son la de Luis Fernández Cifuentes (Zorrilla, 1993), y la versión que realizó Yolanda Pallín para el montaje de la CNTC (Zorrilla, 2000). En esta última, como se dijo anteriormente, se remite a las páginas puesto que los versos no están numerados. 


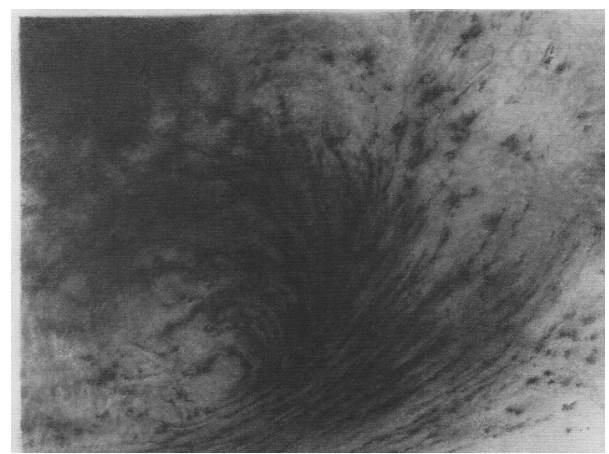

Fig. 5. Telón Hostería, J. Hernández. Boceto para la escenografía de Don Juan Tenorio.

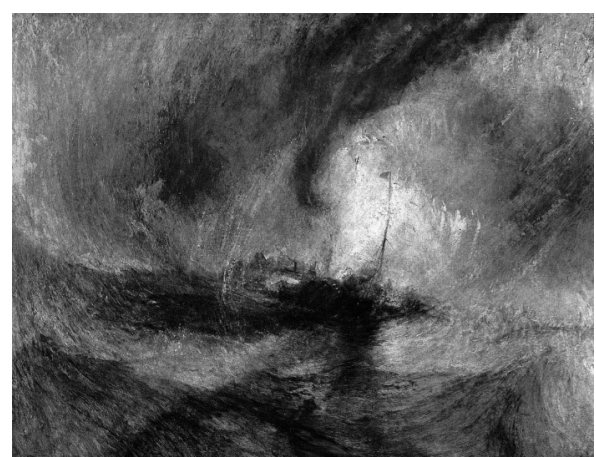

Fig. 6. Tempestad de nieve (1842), William Turner

pictórico de luz y sombra (efectos identificados con la vitalidad y el misterio respectivamente). La constante preocupación por el proceso de creación le llevó a trabajar en torno a elementos como el agua, el fuego o las nubes, todos ellos máximos exponentes de una naturaleza poderosa y sobrecogedora que le permite mostrar lo vulnerable que es el hombre ante lo caótico. Sin duda su mejor ejemplo es Tempestad de nieve (1842) (Fig. 6), donde la fuerza de la naturaleza evoca lo sublime, la categoría estética que persiguen todos los intelectuales románticos.

Esta perturbación emocional nace de contemplar una naturaleza de tal magnitud y despierta la angustia existencial en el individuo, como bien explica la definición que da Étienne Souriau (2010: 729) de 'sublime': «la naturaleza es sublime en aquellos de sus fenómenos donde la intuición suscita la idea de su infinitud». De alguna manera, el telón pintado que Hernández realiza para la hostería de Buttarelli busca evocar ese infinito, y con él, la angustia existencial que don Juan padecerá a lo largo del drama cuya culminación se conoce en la escena final. La angustia existencial también aflora con la categoría de 'tiempo'. El tiempo es el factor que resume la esencia del Don Juan Tenorio de José Zorrilla desde el primer momento. La hostería asiste al encuentro de don Juan y don Luis, que vienen a rendir cuentas con motivo de la apuesta fijada hace un tiempo, y que hoy cumple su plazo, concretamente a las ocho de la noche. El tiempo funciona aquí, y en el resto del drama, como un plazo amenazador que, a pesar de apoyarse en apuestas y conquistas amorosas, escenifica un recurso típico del período romántico: la angustia existencial. Lo que se inicia como un juego (conseguir a dos mujeres en pocos días), se convierte en una apuesta por la vida o por la muerte, que llevará a don Juan a las puertas del mismo Infierno.

El imponente plano existencial de este drama encuentra su reflejo en el telón pintado, cuya virulencia evoca un espacio indefinido, inquietante y agobiante, que conduce a un vacío en el que el hombre parece no tener espacio. Pero, sobre todo, se trata de una solución propiamente goyesca en la que las arquitecturas y las profundidades del fondo de paisaje se ven desplazadas por una masa informe de tra- 


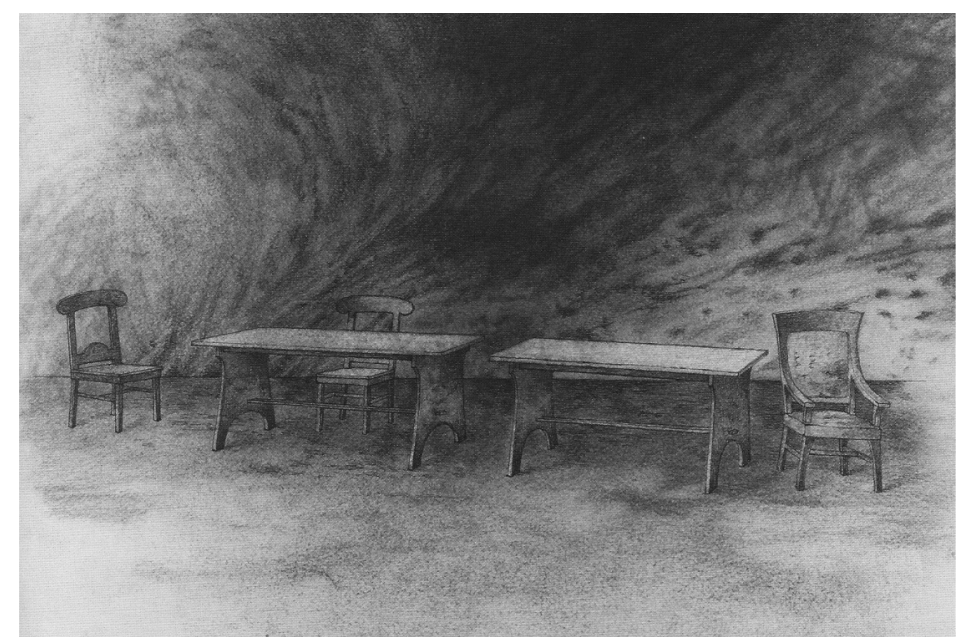

Fig. 7. Mobiliario I, J. Hernández. Muebles de la hostería de Cristófano Buttarelli, Boceto para la escenografía de Don Juan Tenorio.

zos y manchas, nubes aparentes, humos en transición, creadores de escenarios y espacios imprecisos e inciertos. Me refiero a los fondos inaprensibles de la serie grabada de los Disparates y de las Pinturas Negras (ambas compuestas entre 1819-1823), como, por ejemplo, Perro hundiéndose o El aquelarre, ambas pinturas, de esta última serie, en el Museo del Prado de Madrid.

Los muebles de la hostería (Fig. 7) han sido diseñados por Hernández en busca de una armonía cromática con el resto de los elementos de la escena, pues tanto el telón pintado como el vestuario pertenecen a una misma gama cromática, y contribuyen a crear una atmósfera lúgubre; igualmente, los candelabros retorcidos y polvorientos que hay sobre las mesas con unas velas derretidas, son más propios de un relato de terror que de una hostería. Es decir, Hernández ha impregnado toda su escenografía de una connotación siniestra y macabra.

Las máscaras también han sido diseñadas por el pintor, una idea original de Zorrilla que Eduardo Vasco ha querido mantener. Es interesante cómo Zorrilla busca mantener el misterio en este drama con una cita a la que todos ansían acudir, con las máscaras que portan los personajes, con la ocultación y revelación de identidades en momentos concretos del drama, o con la noche como telón de fondo, todo ello unificado bajo la mirada lúgubre y siniestra de la escenografía de José Hernández:

El segundo acto de esta primera parte transcurre en un exterior, como expresa la acotación de Zorrilla: «Exterior de la casa de doña Ana, vista por una esquina. Las dos paredes que forman el ángulo se prolongan igualmente por ambos lados, dejando ver en la de la derecha una reja, y en la de la izquierda una reja y una puerta» (Zorrilla, 1993: 110): 


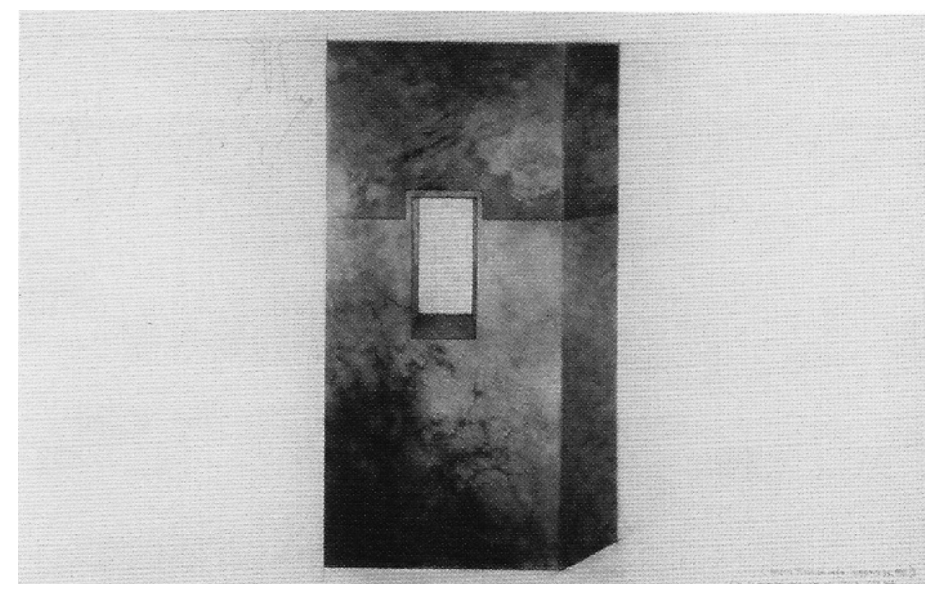

Fig. 8. Casa de doña Ana de Pantoja, J. Hernández. Boceto de la escenografía empleada en Don Juan Tenorio.

José Hernández prescinde de las dos rejas que sugiere Zorrilla en la acotación y resuelve el acto segundo con un muro en dos tonos (gris y negro), dotado de un vano con celosía por donde asomará doña Ana de Pantoja. Dicho muro parece tener volumen al hacer esquina y presentar las sombras correspondientes en el lateral, pero realmente se trata de una superficie pintada; es como si se tratara de un telón pintado aunque el formato es distinto (Fig. 9). Este recurso del trampantojo se empleó a lo largo del Renacimiento en numerosas obras pictóricas, para simular espacios abiertos u otras construcciones ficticias, y Hernández lo recupera en muchas de sus escenografías (no sólo en ésta); una vez más impone el discurso pictórico como una reivindicación de lo ilusorio en el mundo teatral.

En el boceto (Fig. 8), el muro de la casa parece ser de piedra, mármol, o simplemente de mampuesto enlucido por los efectos pictóricos de la superficie. No es la primera vez que Hernández recurre a este tipo de texturas, ya que en el montaje de Amar después de la muerte (2005), dirigido por Eduardo Vasco para la CNTC, diseñó una estructura plegable de tres niveles que buscaba simular con efectos pictóricos una textura marmórea (Fig. 10). El uso de estos módulos que simulan ser de mármol entronca directamente con una técnica muy usada en el siglo XVIII y que queda recogida en el tratado Arte de hacer el estuco jaspeado o de imitar los jaspes a poca costa y con la mayor propiedad de don Ramón Pasqual Díez (1988), publicado en 1785 en Madrid. Este canónigo elaboró este librito para los profesionales de la arquitectura. Su aparición no es casual, sino el resultado de una serie de acontecimientos. A partir de 1720 se publican algunos de los libros que sentarán las bases de la arquitectura de la segunda mitad del siglo XVIII como Compendio Matemático (1727) de Tomás Vicente Tosca o Libro de varios adornos sacados de las mejores fábricas de Roma... (1757) de Domingo Lois Monteagudo. Así mismo por estos años se funda la Real Academia de Bellas Artes de San Fer- 


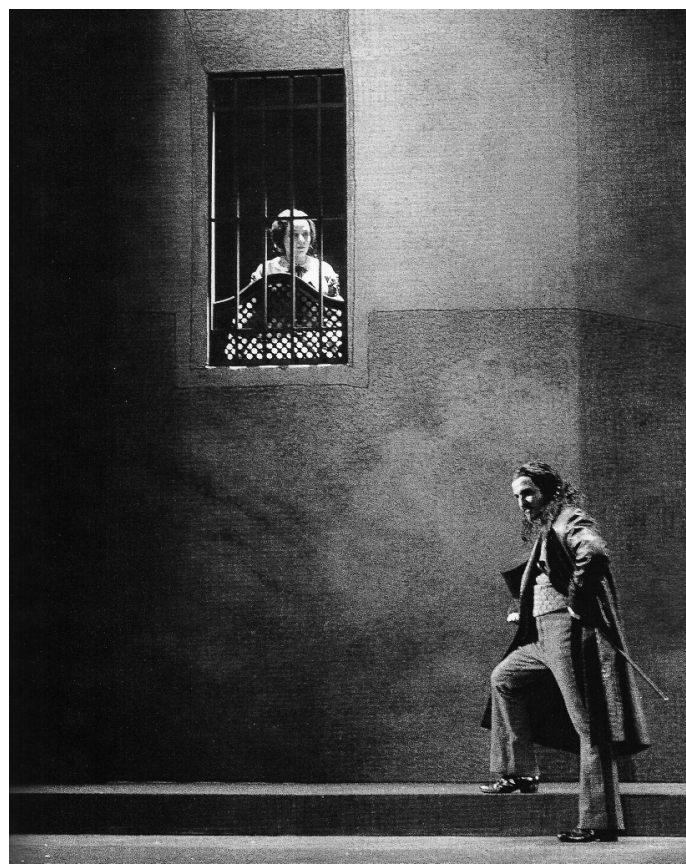

Fig. 9. Puesta en escena de Don Juan Tenorio. Casa de doña Ana de Pantoja.

nando (1744) y poco después las medidas políticas aprobadas por el Conde de Floridablanca directamente relacionadas con las Bellas Artes, entre ellas la prohibición de los retablos de madera en 1777. Por lo tanto, este tratado nace como consecuencia de una notable preocupación por las distintas disciplinas artísticas; prueba de ello es su contenido, organizado en capítulos. El primero de ellos repasa las cualidades del estuco con la intención de mostrar un sinfín de ventajas frente al jaspe. Entre las virtudes del estuco está la posibilidad de superar en belleza al jaspe, la facilidad de reparar cualquier desperfecto así como limpiarlo y manipularlo sin problemas (el jaspe es más frágil y duro que el estuco); igualmente es un material que resulta muy económico, capaz de conseguir idénticos efectos que el jaspe y suplir los retablos de madera que tantos incendios ocasionaban en los lugares de culto. Los materiales que componen el estuco son baratos y accesibles; el yeso blanco o espejuelo es el básico y a él se añaden colores como carmín, añil, albín, etc. Una vez se cubre el armazón con estuco, se pasa a desbastar la pieza que tras una serie de operaciones, alcanza la textura del mármol pulido. Esta simulación de texturas o materiales encaja con la escenografía de José Hernández, en cuyos trabajos siempre persigue el efecto de la ilusión; lo vimos en la escenografía de Don Juan Tenorio, donde la casa de doña Ana de Pantoja simulaba ser una pared de piedra en esquina, tridimensional, cuando realmente era una superficie plana pintada; lo mismo ocurre con la plataforma pintada sobre la que actúan los intérpretes de El castigo sin venganza que aparenta ser un suelo de baldosas: 
Fig. 10. Amar después de la muerte III, J. Hernández. Boceto de la estructura de mármol.
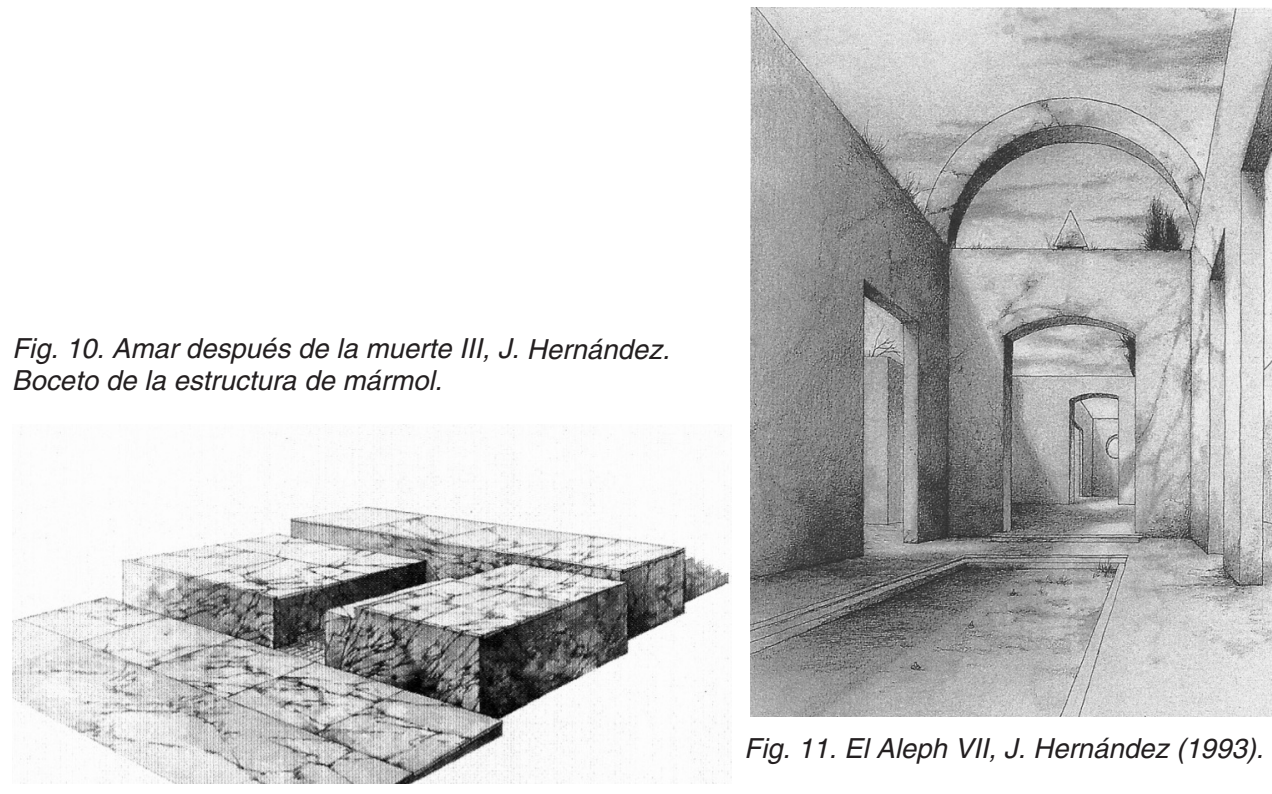

Fig. 11. El Aleph VII, J. Hernández (1993).

En su obra gráfica y pictórica también hay texturas en suelos, ruinas y arquitecturas que simulan piedra, granito, o mármol como en El Aleph VII (1993) (Fig. 11), lo que demuestra una vez más que Hernández aplica el mismo criterio pictórico al grabado, la pintura y el teatro.

El tercer acto de la primera parte se abre con la siguiente acotación de Zorrilla: «Celda de doña Inés. Puerta en el fondo y a la izquierda» (Zorrilla, 1993: 134):

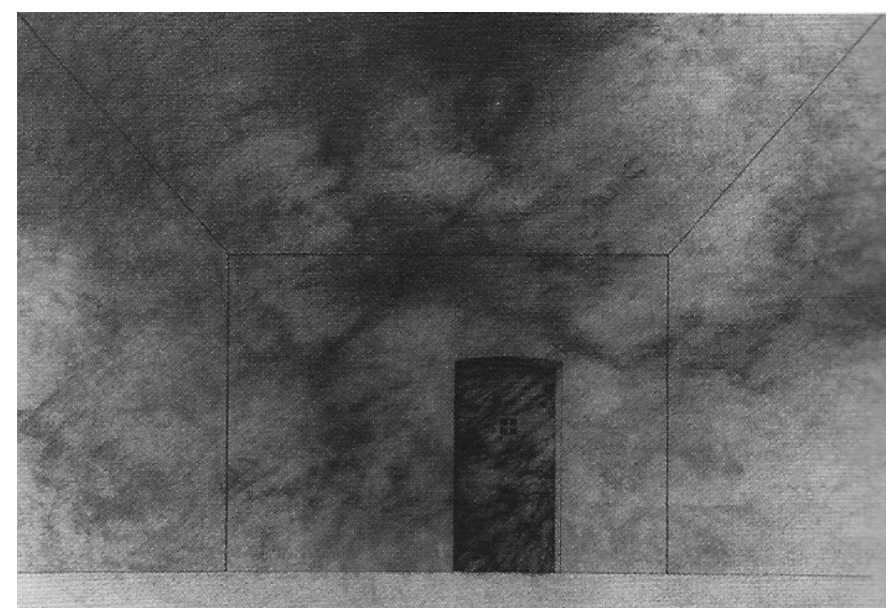

Fig. 12. Puerta, J. Hernández. Boceto para la escenografía de la celda de doña Inés. 
Hernández ha resuelto la escenografía de la celda con un telón pintado (Fig. 12). A diferencia del primero que se limitaba a una mancha, este telón busca el efecto de profundidad a través de unas líneas que marcan la perspectiva de la celda, consiguiendo así un espacio ilusorio. De nuevo la pátina color sepia se impone sobre la puerta y las paredes, dotando a la escena de un color apagado que contrasta con el vestuario blanco de la Orden de las Calatravas a la que pertenecen doña Inés y la Abadesa, lo que nos anima a establecer asociaciones cromáticas: el bien, la pureza, lo virginal y la redención quedan representados en el blanco; el mal, la pasión, el pecado y la muerte quedan patentes a través del sepia o gris de toda la escenografía, como elementos amenazantes. De nuevo se repite el jaspeado en toda la superficie del telón para simular que se trata de una construcción sólida, de textura pétrea o marmórea.

El último acto de la primera parte (el cuarto) se apoya en la siguiente acotación: "Quinta de don Juan Tenorio cerca de Sevilla y sobre el Guadalquivir. Balcón en el fondo. Dos puertas a cada lado» (Zorrilla, 1993: 152). José Hernández diseña dos telones. El telón del fondo (Fig. 16) recrea un espacio al aire libre, en el que pueden apreciarse las nubes del cielo y, en la parte baja, algo de vegetación (semejante a juncos o hierba). Delante de éste hay otro telón (Fig. 15) en cuya parte inferior se abre un vano con forma de ajimez, es decir, una ventana de dos luces

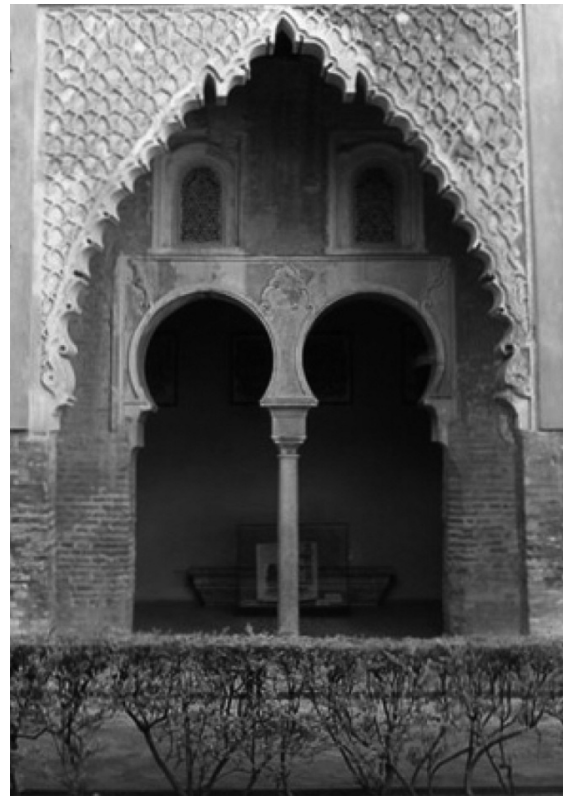

Fig. 13. Ajimez del Patio del yeso del Alcázar de Sevilla.

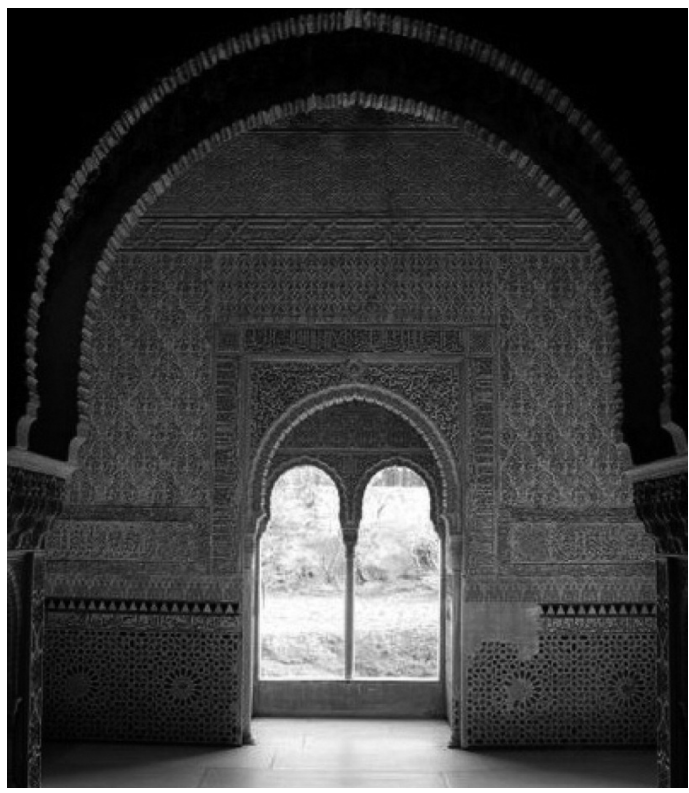

Fig. 14. Interior de la Torre de la cautiva en la Alhambra, con un ajimez al fondo. 
divididas por una columna, una solución muy habitual en la arquitectura islámica y de la que pueden encontrarse ejemplos fácilmente en el Alcázar de Sevilla (Fig. 13), y en la Alhambra de Granada (Fig. 14).

La utilización de una referencia a lo exótico a través de la arquitectura musulmana, es un gesto propio del Romanticismo que, como ya dijimos, forma parte del imaginario artístico de Hernández y entronca directamente con la época de Zorrilla. Uno de los ejemplos más claros es Los cuentos de la Alhambra (1829) de Washington Irving (1783-1859) que no se inspira en esta construcción islámica por casualidad; en el siglo XIX la Alhambra se encontraba en muy mal estado (desde que se sumiera en abandono a mediados del siglo XVIII), y si la arquitectura islámica ya suponía objeto de inspiración por su exotismo, se añade ahora el valor estético de la ruina que tanto atraía a los artistas y escritores del Romanticismo. Por este motivo, fueron muchos los intelectuales inspirados en este complejo arquitectónico, uno de los ejemplos más representativos del arte hispanomusulmán. A ello cabe añadir que Zorrilla ubica su drama en Andalucía, más concretamente en Sevilla, (de hecho, la quinta de don Juan está junto al río Guadalquivir), por lo que no es de extrañar que Hernández haya optado por una referencia arquitectónica islámica poniendo de relieve la coherencia que ha buscado el escenógrafo entre texto y representación (Fig. 17):

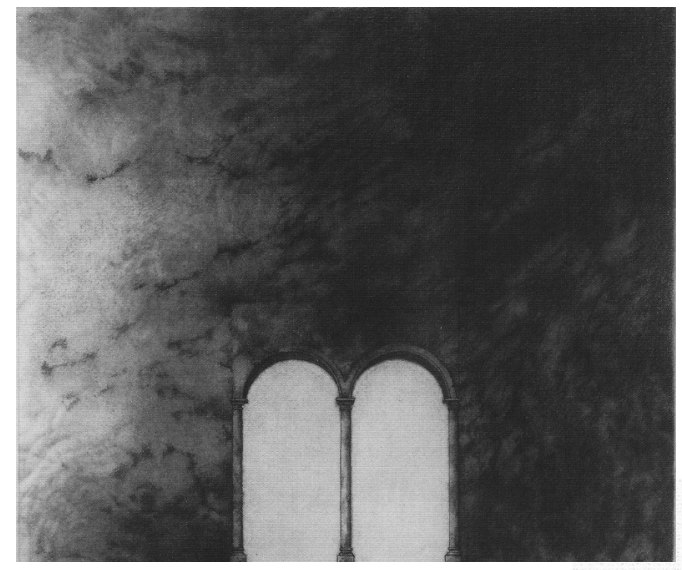

Fig. 15. Telón quinta de don Juan, J. Hernández. Boceto de la escenografía empleada en el acto cuarto de la primera parte de Don Juan Tenorio. 


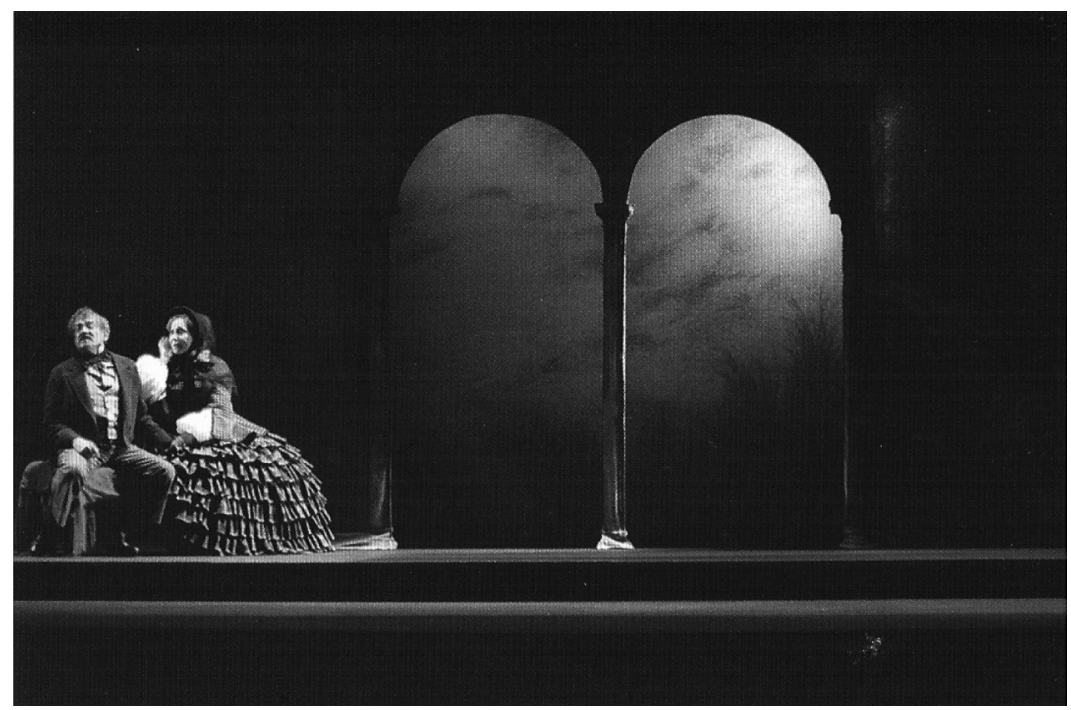

Fig. 17. Puesta en escena de Don Juan Tenorio. Quinta de don Juan

Este último acto acaba con la llegada de don Luis, con el rostro oculto tras una máscara, para retar a don Juan a un duelo. Mueren don Luis y don Gonzalo a manos del libertino. Con la llegada de los soldados se oscurece el escenario, quedando iluminados los dos arcos de la quinta y el rostro de don Juan que pronuncia estos versos: «Llamé al cielo y no me oyó, / y pues sus puertas me cierra, / de mis pasos en la tierra / responda el cielo, y no yo.» (Zorrilla, 2000: 75), cerrándose el acto cuarto y finalizando así la primera parte de Don Juan Tenorio.

La segunda parte está formada por tres actos, acompañados de tres escenografías diferentes:

El primer acto de la segunda parte presenta una larga acotación, en la que se ha inspirado el escenógrafo para elaborar, de nuevo, un telón pintado:

Panteón de la familia Tenorio. El teatro representa un magnífico cementerio, hermoseado a manera de jardín. En primer término, aislados y de bulto, los sepulcros de don Gonzalo de Ulloa, de doña Inés y de don Luis Mejía, sobre los cuales se ven sus estatuas de piedra. El sepulcro de don Gonzalo a la derecha, y su estatua de rodillas; el de don Luis a la izquierda, y su estatua también de rodillas; el de doña Inés en el centro, y su estatua de pie. En segundo término otros dos sepulcros en la forma que convenga; y en el tercer término y en puesto elevado, el sepulcro y estatua del fundador don Diego Tenorio, en cuya figura remata la perspectiva de los sepulcros. Una pared llena de nichos y lápidas circuye el cuadro hasta el horizonte. Dos llorones a cada lado de la tumba de doña Inés, dispuestos a servir de la manera que a su tiempo exige el juego escénico. Cipreses y flores de todas clases embellecen la decoración, que no debe tener nada de horrible. La acción se supone en una tranquila noche de verano, y alumbrada por una clarísima luna (Zorrilla, 1993: 179): 


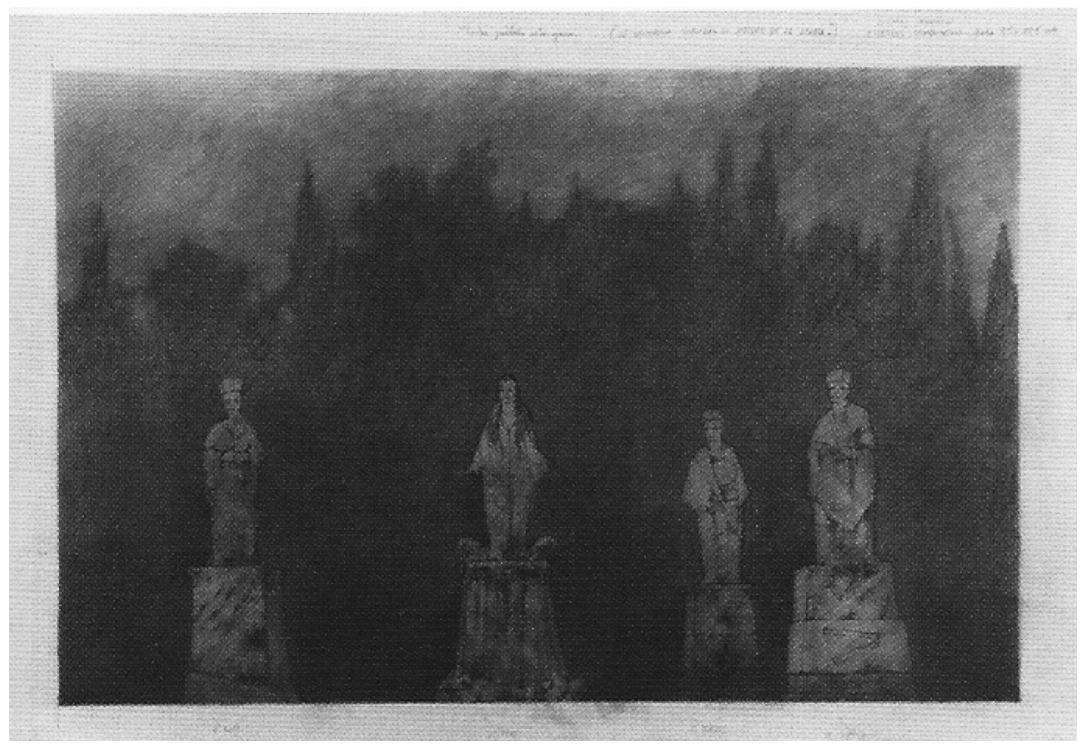

Fig. 18. Telón pintado sobre gasa (estatuas), J. Hernández. Boceto para la escenografía de Don Juan Tenorio.

Ahora cuatro focos de luz dibujan líneas verticales que caen del techo sobre las cuatro esculturas del panteón (que corresponden a don Gonzalo Ulloa, doña Inés, don Luis Mejía y don Diego Tenorio), dibujadas en un telón pintado sobre gasa (Fig. 18), un material que consigue efectos lúgubres por no dejar apreciar nítidamente lo que en él hay dibujado. Estas esculturas hechas de mármol de Carrara (según el Escultor) muestran la textura que tanto se ha repetido en la escenografía de este montaje, la del jaspe. En relación con la aparición de doña Inés, el director ha resuelto esta escena proyectando el rostro de la novicia (de inmensas proporciones) sobre el telón. El paso al segundo acto tiene lugar tras el convite que hace don Juan al comendador.

El segundo acto transcurre en el aposento de don Juan, cuya escenografía ha sido diseñada al margen de la acotación de Zorrilla. José Hernández ha reducido el espacio escénico a cuatro sillas de altos respaldos, cubiertas por unas telas que Ciutti retira al comenzar la escena, un candelabro de pie y una mesa con todos los objetos propios de un convite (cubiertos, vasos, platos, botellas, etc.), pero todos estos objetos han sido diseñados con un carácter tétrico (Fig. 19); da la sensación de que los muebles han sido elaborados en hueso (por las formas de las patas y de los ángulos) y los respaldos de las sillas parecen haberse quedados fosilizados por el paso del tiempo, o bien da la sensación de que están ocultos por una gruesa capa de polvo y telarañas. A ello contribuye el color de estos muebles y objetos: un gris claro que contrasta con un fondo oscuro (a diferencia de otras propuestas finalmente desechadas (Fig. 20)). 


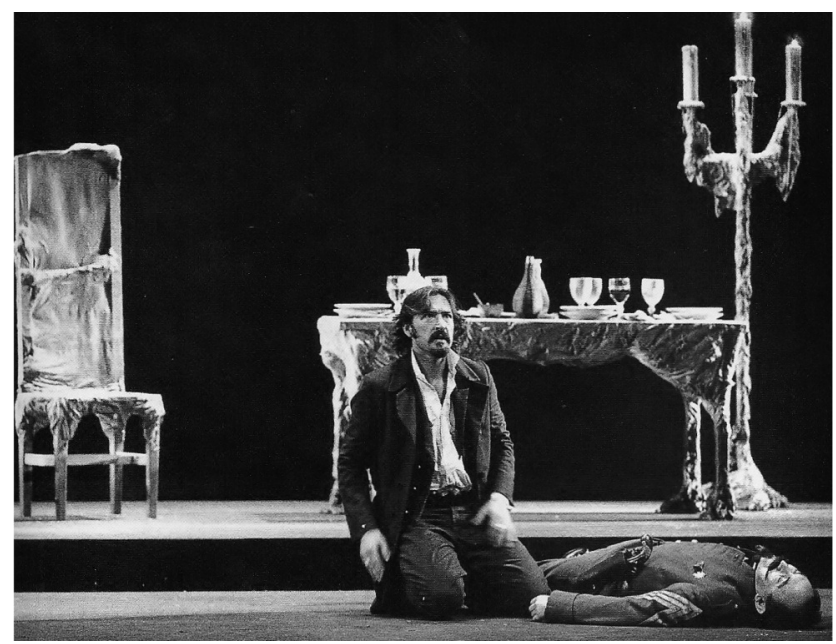

Fig. 19. Puesta en escena de Don Juan Tenorio. Aposento de don Juan.

En la última parte del drama, se ha prescindido de gran parte del espectáculo de visiones y transformación del entorno que sugiere el autor en su acotación: «Panteón de la familia Tenorio. Como estaba en el acto primero de la segunda parte, menos las estatuas de doña Inés y de don Gonzalo, que no están en su lugar» (Zorrilla, 1993: 216).

En el montaje final, tan sólo se ha mantenido la idea de las sombras y espíritus que ocupan el fondo del escenario, desechando algunos bocetos que resultaban mucho más fieles al texto de Zorrilla. El Comendador hace acto de presencia en la

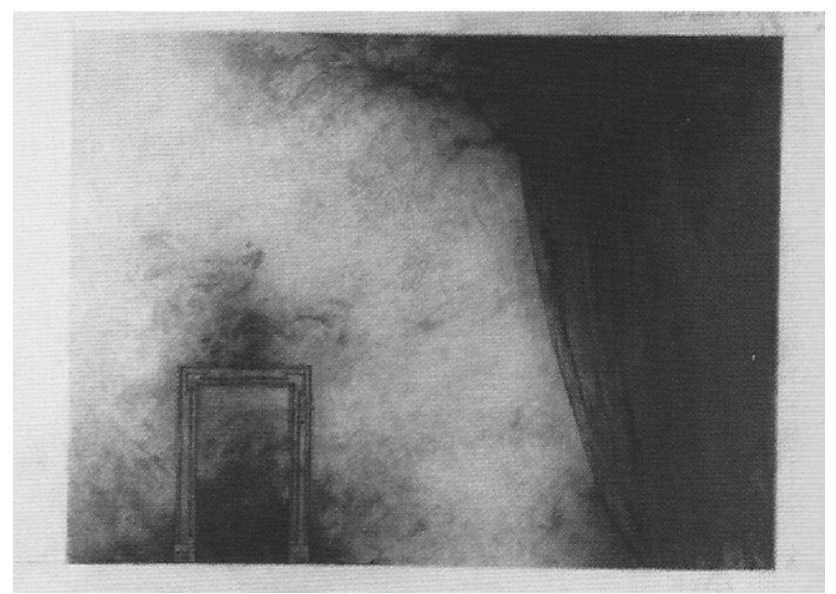

Fig. 20. Telón aposento de don Juan, J. Hernández. Boceto de la escenografía del aposento de don Juan, no utilizado en el montaje final. 


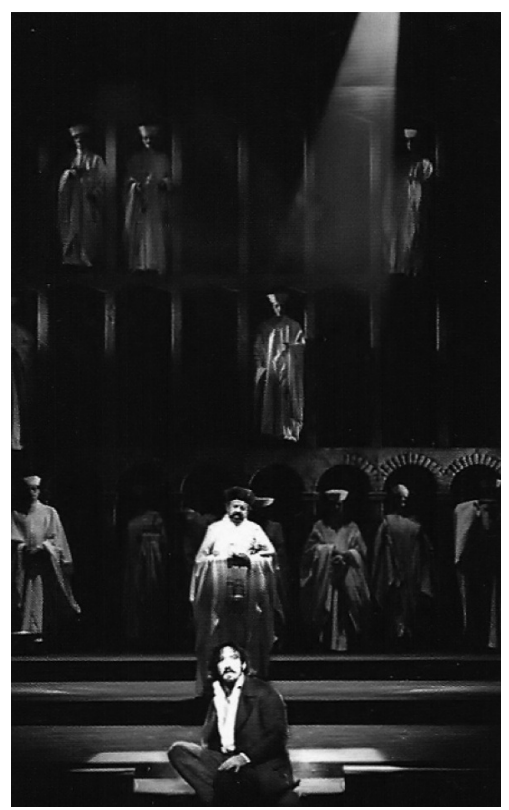

Fig. 21. Puesta en escena de Don Juan Tenorio.

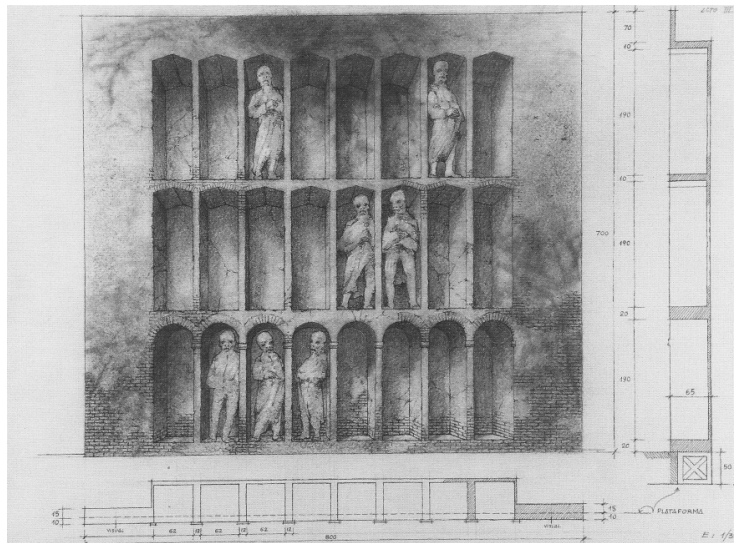

Fig. 22. Acto III y planta, J. Hernández. Boceto para la escenografía de Don Juan Tenorio.

segunda escena con una estructura de tres cuerpos a sus espaldas. Se trata de una construcción arquitectónica de piedra (Fig. 22), que tiene tres niveles construidos a partir de nichos; los dos niveles superiores están cerrados por una cubierta a dos aguas, mientras que el tercer nivel (a ras de suelo) presenta nichos que culminan en arcos de medio punto. Por algunos de ellos asoman figuras humanas vestidas de blanco que representan las ánimas de los caídos a manos de don Juan, sus fantasmas; ha llegado el momento de impartir justicia divina. Mientras el Comendador habla, don Juan le escucha sentado en las escaleras que hay al borde del escenario, con un cuadrado de luz roja proyectado en el suelo que queda a sus espaldas y que parece ser la boca del Infierno (Fig. 21). Uno de los bocetos de Hernández contaba con un inmenso reloj de arena, el que mide el tiempo que le queda a don Juan antes de que el Comendador le arrastre al submundo, pero finalmente no se incorporó al montaje (Fig. 23).

En el montaje de Vasco, don Juan queda tendido en el suelo mientras un telón con un cielo pintado baja lentamente y ocupa el fondo del escenario, fuertemente iluminado. Entonces doña Inés recita los últimos versos mientras avanza por el pasillo del patio de butacas hacia don Juan, retirándose los dos por este mismo corredor agarrados de la mano. El telón del cielo (Fig. 24) según su boceto, mide 7,20 x 11,00 metros. Y es así como el recurso más empleado por Hernández en sus colaboraciones teatrales, pone el broche final a Don Juan Tenorio: 


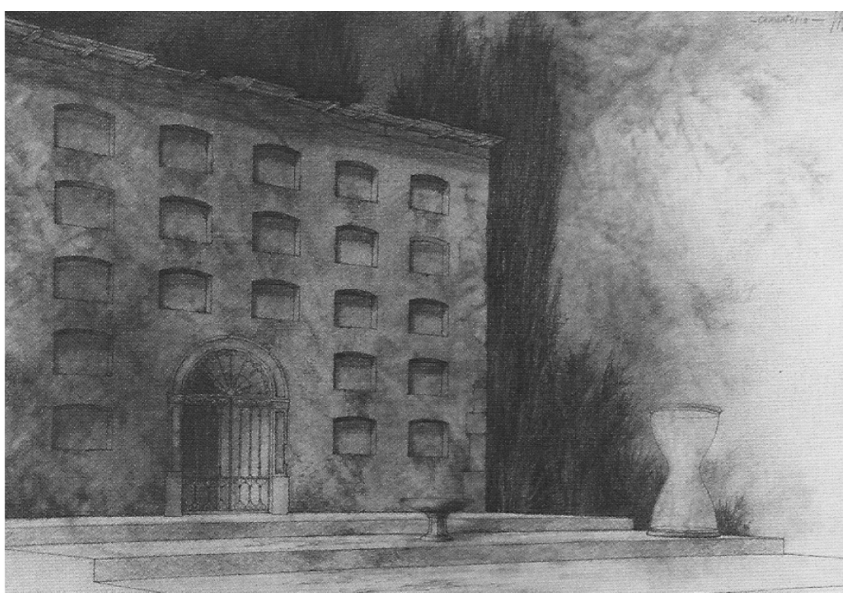

Fig. 23. Cementerio, J. Hernández. Boceto para la escenografía de Don Juan Tenorio, no usado en el montaje final.

Es indudable que en la escenografía de José Hernández para Don Juan Tenorio, el autor ha acudido a una recreación romántica, recurriendo a muchos de sus «topoi» ideológicos para establecer un nuevo desarrollo plástico y formal, un planteamiento que a pesar de no ser mimético con el tiempo de la obra, sí ha perseguido la armonización con el espíritu del texto. A través de ello, José Hernández, como en todas sus escenografías, desarrolla un lenguaje integrado en el que destaca su carácter personal e innovador.

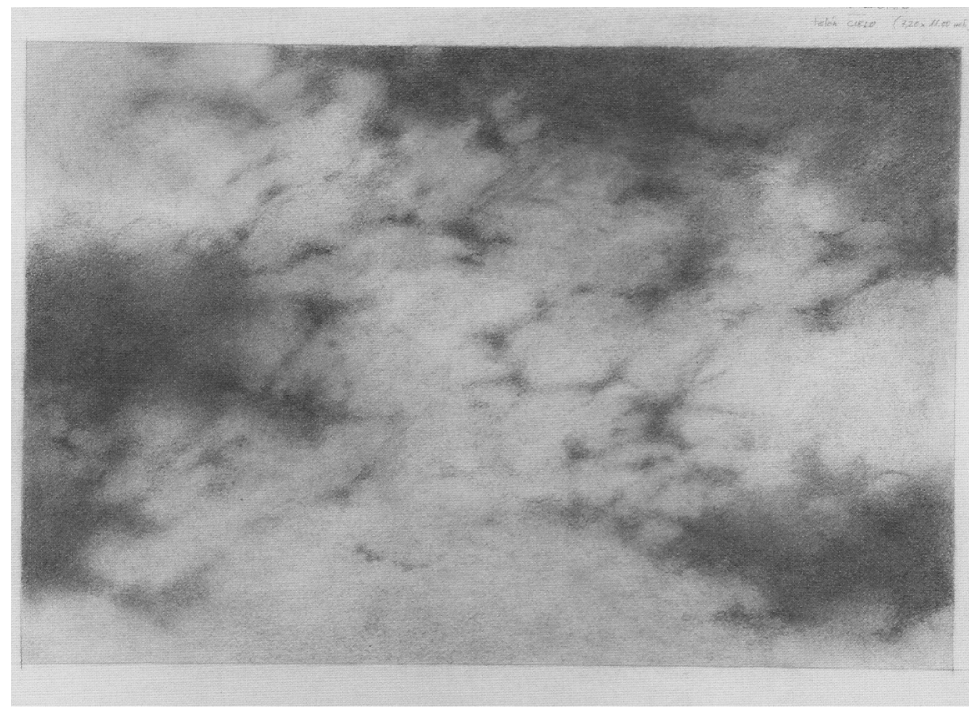

Fig. 24. Telón cielo, J. Hernández.

Boceto para la escenografía de la escena final de Don Juan Tenorio. 


\section{REFERENCIAS BIBLIOGRÁFICAS}

BERLIN, I. (2000). Las raíces del Romanticismo. Madrid: Taurus.

BURKE, E. (2001). Indagación filosófica sobre el origen de nuestras ideas acerca de lo sublime y de lo bello. Madrid: Tecnos.

CALVO SERRALLER, F. (2005). José Hernández. Barcelona: March Editor.

FREIRE LÓPEZ, A. M. (2009). El teatro español entre la llustración y el Romanticismo. Madrid durante la Guerra de la Independencia. Madrid: Iberoamericana.

LIPSCHUTZ, I. H. (1988). La pintura española y los románticos franceses. Madrid: Taurus.

NIETO ALCAIDE, V. (1993). «El color de la negación del color». En El color de las vanguardias. Pintura española contemporánea 1950-1990 en la colección Argentaria. Madrid: Fundación Argentaria.

NIEVA, F. (2008). José Hernández y el teatro. 1973-2007. Alcalá de Henares: Ayuntamiento de Alcalá de Henares, Colegio del Rey.

PASCUAL DÍEZ, R. (1988). Arte de hacer el estuco jaspeado o de imitar los jaspes a poca costa y con la mayor propiedad. Valladolid: Colegio Oficial de Arquitectos de Valladolid.

SOURIAU, E. (2010). Diccionario Akal de Estética. Madrid: Akal.

VV.AA. (1981). Imagen romántica de España. Madrid: Ministerio de Cultura.

ZORRILLA, J. (1993). Don Juan Tenorio. Barcelona: Crítica.

- (2000). Don Juan Tenorio. Madrid: Compañía Nacional de Teatro Clásico (Textos de Teatro Clásico, nํㅜㄹ).

ZUBIETA (2004). Seis caminos hacia el mito de Don Juan. Madrid: Compañía Nacional de Teatro Clásico (Cuadernos de Teatro Clásico, no 19). 